\title{
Pengembangan Penataan Perparkiran Universitas Hasanuddin Di Fakultas Teknik, Fakultas Mipa Dan Fakultas Farmasi
}

\author{
Development of Parking Arrangement at Hasanuddin University in the Faculty of \\ Engineering, Faculty of Mathematics and Natural Sciences and Faculty of Pharmacy \\ Andi Fathussalam Baharuddin ${ }^{1 *}$, M. Yamin Jinca ${ }^{1}$, Jamaluddin Rahim ${ }^{1}$ \\ *Email: fathussalam.baharuddin@gmail.com \\ ${ }^{1}$ Program Studi Teknik Perencanaan Transportasi Fakultas Teknik Universitas Hasanuddin
}

Diterima: 12 September 2021 / Disetujui: 24 Desember 2021

\begin{abstract}
ABSTRAK
Meningkatnya pemilikan kendaraan bermotor civitas akademika Universitas Hasanuddin mengakibatkan peningkatan permintaan fasilitas parkir mengingat fasilitas parkir merupakan bagian yang tak terpisahkan dari sistem transportasi sehingga menimbulkan kesemrawutan perparkiran seperti yang dilihat pada area perparkiran Fakultas Teknik, Fakultas MIPA dan Fakultas Farmasi. Tujuan penelitian ini, yaitu menyusun konsep penataan ruang parkir yang dapat menjelaskan kapasitas ruang parkir efektif ditinjau berdasarkan tata layout bangunan dan kebutuhan parkir Fakultas Teknik, Fakultas MIPA, dan Fakultas Farmasi di Universitas Hasanuddin Tamalanrea, Makassar menggunakan metode penelitian deskriptif kuantitatif dalam menganalisis karakteristik parkir untuk mengetahui kapasitas parkir, volume parkir, akumulasi parkir, tingkat penggunaan parkir, dan kebutuhan parkir kendaraan roda dua dan roda empat yang keluar-masuk area parkir selama lima hari kerja mulai pukul 06.30 sampai dengan pukul 17.30 dengan hasil penelitian menunjukkan bahwa penyusunan sebuah konsep penataan ruang parkir efektif di lingkungan tiga fakultas di Universitas Hasanuddin (Teknik, MIPA, dan Farmasi) berhasil disusun dengan merekomendasikan penggabungan beberapa lahan parkir menjadi satu area parkir kendaraan roda empat dan sentralisasi parkiran kendaraan beroda dua.
\end{abstract}

Kata Kunci: Kampus, Perparkiran, Ruang Parkir

\section{ABSTRACT}

The increasing number of vehicles ownership among the Hasanuddin University academic community resulted in increased demand for parking facilities; considering it is an integral part of the transportation system, the steep demands causing parking disorganize as seen in the parking facilities of the Faculty of Engineering, Faculty of Science and Faculty of Pharmacy. This study attempts to propose a parking spaces rearrangement that could describe the effective capacity of parking area from the standpoint of the building layout planning and the parking spaces needs of the Faculty of Engineering, Faculty of Science and Faculty of Pharmacy at the University of Hasanuddin Tamalanrea Makassar. Using descriptive quantitative research method in analyzing the characteristics of parking to determine the capacity of parking, parking volume, accumulated parking, parking usage levels, and the need for parking of the two-wheeled and four-wheeled vehicles entered and exited the parking area for five working days; starting at 06:30 AM until 17.30 $P M$, resulting a concept of an effective parking spaces rearrangement that encompassing the three faculty of Hasanuddin University (faculty of Engineering, Sciences, and Pharmacy) by recommending the incorporation of several of the parking lot into a four-wheeled vehicle parking areas and centralized parking facilities for two-wheeled vehicles.

Keywords: Campus, Parking, Parking Spaces

(c) (9) This work is licensed under Creative Commons Attribution License 4.0 CC-BY International license 


\section{A. PENDAHULUAN}

Universitas adalah suatu miniatur sebuah perkotaan lengkap dengan segala permasalahan dan persoalan yang menyertainya. Perkembangan sebuah universitas tergantung dari faktor-faktor pendukungnya seperti sumber daya manusianya, sarana dan prasarananya, dana yang tersedia dan sumber daya pendukung lainnya.

Menurut Abubakar dkk., (1998), parkir didefinisikan sebagai keadaan tidak bergerak suatu kendaraan yang tidak bersifat sementara: termasuk dalam pengertian parkir adalah setiap kendaraan yang berhenti pada tempat-tempat tertentu baik yang dinyatakan dengan rambu ataupun tidak, serta tidak semata-mata untuk kepentingan menaikkan dan atau menurunkan orang dan barang.

Semakin besar volume lalu lintas yang beraktivitas baik yang meninggalkan atau menuju pusat kegiatan, maka semakin besar pula kebutuhan ruang parkir, bila tidak cukup kendaraan tersebut akan mengambil parkir di tepi jalan di sekitar kawasan tersebut, sehingga menyebabkan kesemrawutan. Permasalahan parkir sangat penting untuk dikaji lebih mendalam, selain itu, lalu lintas dalam kampus merupakan topik yang saat ini banyak diangkat oleh peneliti-peneliti bidang transportasi (Shang et al., 2007).

Universitas menyediakan tempat bagi staff dan mahasiswa untuk bekerja, belajar dan tempat tinggal. Parkiran adalah salah satu topik penting dalam perencanaan dan manajemen transportasi. Telah banyak peneliti-peneliti bidang transportasi yang telah meneliti permasalahan parkir pada sebuah kampus seperti permasalahan parkir di Beijing Universty of Aeronautics and Astronaunatics (BUAA), Tiongkok. BUAA sebagai urban campus menghadapi permasalahan terbatasnya lahan parkir dengan pertumbuhan jumlah kendaraan yang meningkat. Permasalahan serupa juga diteliti oleh Barata et al.,(2011), yang meneliti permasalahan perparkiran di University of Coimbra (UC) Portugal. Penelitian pada aspek sosioekonomi dengan mengedepankan karakteristik komuter dan pilihan-pilihan yang mereka ambil dalam bepergian. Rotaris \& Danielis (2014), meneliti dampak dari kebijakan-kebijakan TDM terhadap perilaku pegawai, dosen dan mahasiswa dalam menggunakan kendaraan di University of Trieste, Italia.

Tujuan penelitian ini, yaitu menyusun konsep penataan ruang parkir yang dapat menjelaskan kapasitas ruang 
parkir efektif ditinjau berdasarkan tata layout bangunan dan kebutuhan parkir Fakultas Teknik, Fakultas MIPA, dan Fakultas Farmasi di Universitas Hasanuddin Tamalanrea, Makassar menggunakan metode penelitian deskriptif kuantitatif dalam menganalisis karakteristik parkir untuk mengetahui kapasitas parkir, volume parkir, akumulasi parkir, tingkat penggunaan parkir, dan kebutuhan parkir kendaraan roda dua dan roda empat yang keluarmasuk area parkir selama lima hari kerja mulai pukul 06.30 sampai dengan pukul 17.30.

\section{B. METODE PENELITIAN \\ 1. Lokasi Penelitian}

Penelitian ini akan dilakukan di Area Parkir Fakultas Teknik, Fakultas MIPA dan Fakultas Farmasi Universitas Hasanuddin Tamalanrea Makassar. Lokasi penelitian ini diambil karena ketiga fakultas yang berdekatan dan mempunyai akses jalan masuk yang sama dan telah terjadi kesemrawutan parkir sehingga terkesan sangat kumuh dikarenakan tata kelola parkir yang seadanya tanpa perhitungan yang baik, hal ini mulai bertambah parah ketika Fakultas MIPA membangun gedung baru tanpa parkiran yang baik disusul pembangunan gedung baru Fakultas Farmasi tanpa konsep parkir yang memadai sehingga akses pejalankaki berubah menjadi parkir motor, taman pinggir jalan berubah menjadi parkir motor dan mobil. Penelitian ini bisa menjadi acuan pengelolaan parkiran di UNHAS pada umumnya karena permasalahan di semua Fakultas adalah keterbatasan lahan parkir

\section{Populasi dan Sampel}

Populasi dalam penelitian ini adalah pengunjung tetap yaitu keseluruhan jumlah pegawai/karyawan, mahasiswa, dosen Fakultas Teknik, Fakultas MIPA dan Fakultas Farmasi Universitas Hasanuddin Makassar sebanyak 7920 orang. Adapun jumlah populasi pengunjung yang tidak tetap atau sementara di kawasan tersebut jumlahnya tidak diketahui dengan pasti.

Ditinjau dari sifatnya, populasi dapat bersifat homogen dan heterogen. Populasi yang bersifat homogen artinya populasi tersebut mempunyai karakteristik yang sama, sehingga tidak perlu mempersoalkan berapa banyak jumlah ukuran sampel yang harus diambil. Sedangkan populasi yang bersifat heterogen artinya setiap anggota sampel dari populasi tersebut mempunyai karakteristik yang berbeda, sehingga perlu ditetapkan batasan-batasannya baik secara kualitatif maupun kuantitatif. Populasi 
dalam penelitian ini bersifat heterogen, yaitu populasi pengunjung tetap seperti pegawai/karyawan, mahasiswa dan dosen, sedangkan populasi pengunjung sementara yaitu mahasiswa fakultas lain, tukang ojek, pedagang, tamu fakultas, dan sebagainya.

\section{Pengumpulan Data}

Penyusunan penelitian ini dimulai dengan melakukan survey pendahuluan yaitu pengamatan langsung di lokasi penelitian mengenai kondisi eksisting perparkiran dan permasalahannya. Kemudian dilanjutkan oleh survey utama yang pelaksanaannya dilakukan secara bersamaan untuk pengumpulan data di lapangan mengenai volume kendaraan, ukuran dan lebar gang parkir, kapasitas parkir, dan durasi parkir.

Surveyor ditempatkan pada gerbang masuk menuju Fakultas Teknik, Fakultas Farmasi dan Fakultas MIPA untuk menghitung jumlah kendaraan roda dua dan roda empat yang masuk, keluar dan parkir dari dan menuju lokasi parkir. Kendaraan roda dua mencakup sepeda motor sedangkan kendaraan roda empat mencakup mobil penumpang dan mobil bak terbuka/kanvas pengangkut logistik. Pengamatan dilakukan selama lima hari kerja Senin s/d Jumat dimulai dari pukul
06.30 sampai dengan pukul 17.30 dengan membagi empat periode analisis, yaitu: Periode I : merupakan analisis parkir yang terjadi antara pukul 06.30 - 09.00. Periode II : merupakan analisis parkir yang terjadi antara pukul $09.00-12.00$. Periode III : merupakan analisis parkir yang terjadi antara pukul $12.00-15.00$.

Periode IV : merupakan analisis parkir yang terjadi antara pukul 15.00 - 17.30.

Tabel 1. Data Inventaris Parkir

\begin{tabular}{|c|c|c|c|c|}
\hline Kendaraan & Jenis Parkir & Lahan & Luas $\left(m^{2}\right)$ & Jumlah Petak \\
\hline \multirow{4}{*}{ Mobil } & \multirow{4}{*}{ Off-street } & Terminal Fakultas Teknik (Al) & 609.5 & 50 \\
\hline & & $\begin{array}{l}\text { Science Building Fakultas MIPA } \\
\text { (A2) }\end{array}$ & 249.82 & 11 \\
\hline & & Depan Gedung Fakultas Farmasi (A3) & & 11 \\
\hline & & Parkiran Fakultas Farmasi (A4) & 264.16 & 20 \\
\hline \multirow{8}{*}{ Motor } & & Lab. Mektan Sipil (C1) & $\begin{array}{c}\mathbf{1 1 2 3 . 4 8} \\
202\end{array}$ & $\begin{array}{c}\mathbf{9 2} \\
132\end{array}$ \\
\hline & \multirow{7}{*}{ Off-street } & TNR (C2) & 240 & 85 \\
\hline & & Gerbang Fakultas MIPA (C3) & 290.8 & 207 \\
\hline & & Gedung POMD Fak.Teknik (C4) & 136.6 & 100 \\
\hline & & Parkiran Geologi (C5) & 245.3 & 197 \\
\hline & & Jalan Lama Gedung PBT 1 (C6) & 90.06 & 67 \\
\hline & & Jalan Lama Gedung PBT 2 (C7) & 69.5 & 52 \\
\hline & & Jalan Lama Gedung PBT 3 (C8) & 22.8 & 16 \\
\hline \multicolumn{2}{|c|}{ Total } & & 1297.06 & 825 \\
\hline
\end{tabular}

\section{Analisis Data}

Menurut Morlok (2010), fasilitas parkir diklasifikasikan sesuai dengan tiga karakteristik utamanya, yang pertama adalah apakah parkir tersebut disediakan pada jalan atau di luar jalan, yang kedua tergantung pada apakah parkir tersebut dilakukan oleh pengemudi sendiri atau oleh petugas parkir khusus dan yang ketiga adalah perbedaan fasilitas parkir berlantai tunggal atau berlantai banyak. Analisis data kuantitatif merupakan tahapan untuk menentukan permasalahan yang dihadapi dengan menganalisis karakteristik parkir yang akan diperoleh melalui: 
Akumulasi parkir yaitu jumlah kendaraan yang diparkir pada suatu tempat pada waktu tertentu yang menunjukkan beban parkir (jumlah kendaraan parkir) per periode waktu tertentu.

$$
\text { Akumulasi }=\mathrm{Ei}-\mathrm{Ex}+\mathrm{X}
$$

\section{Dengan :}

$\mathrm{Ei}=$ Entry (kendaraan yang masuk lokasi)

Ex $=$ Exit (kendaraan yang keluar lokasi)

$\mathrm{X}=$ jumlah kendaraan yang telah parkir sebelum pengamatan

Volume parkir ditentukan dengan mengambil jumlah maksimum kendaraan parkir pada satu hari dari lima hari pengamatan. Kebutuhan ruang parkir dihitung dengan menggunakan rumus:

$$
K R P=\text { Volume Parkir } x S R P_{(\text {motor/mobil })}
$$

Parking Turn Over (PTO) yaitu tingkat pergantian parkir yang menunjukkan tingkat penggunaan ruang parkir dalam satuan waktu tertentu. Tingkat pergantian parkir menunjukkan tingkat penggunaan ruang parkir, dihitung dengan rumus:

PTO $=\frac{\text { Jumlah kendaraan masuk dalam satu periode }}{\text { Akumulasi parkir maksimum dalam satu har } i}$

Satuan ruang parkir (SRP) adalah ukuran luas efektif untuk meletakkan kendaraan (mobil penumpang, bus/truk atau sepeda motor), termasuk ruang bebas dan lebar bukaan pintu. Dapat pula dikatakan bahwa SRP merupakan ukuran kebutuhan ruang untuk parkir suatu kendaraan dengan nyaman dan aman dengan besaran ruang yang seefisien mungkin. Satuan ruang parkir (SRP) yang digunakan merujuk Keputusan Menteri Perhubungan Nomor: 272/HK.105.DRJD/96 untuk motor adalah $0.7 \mathrm{~m} \times 2 \mathrm{~m}$ dan untuk mobil adalah $2.5 \mathrm{~m} \times 5 \mathrm{~m}$.

Analisis kualitatif merupakan desain tata layout parkiran meninjau kapasitas ruang parkir berdasarkan data mengenai sempadan jalan terhadap ruang parkir, ukuran ruang parkir dan lebar gang parkir, sistem sirkulasi, pengaturan akses masuk dan keluar, serta pemilihan sudut parkir.

\section{HASIL DAN PEMBAHASAN}

Pemberian pakan suplemen UMMB pada induk kambing bunting pada kambing Peranakan Etawa dan kambing Kacang yang diberikan pada waktu umur kebuntingan yang berbeda di tampilkan pada tabel 1, memperlihatkan rata-rata pertambahan berat badan induk yang berbeda untuk setiap umur kebuntingan.

Rata-rata terdapat kurang lebih 2000 kendaraan roda dua dan lebih dari 200 kendaraan roda empat yang tercatat keluar dan masuk Fakultas Teknik, Fakultas Farmasi dan Fakultas MIPA. Pada hari selasa akumulasi seluruh kendaraan merupakan hari di mana jumlah kendaraan parkir tercatat paling tinggi. Terjadi lonjakan kendaraan masuk 
pada periode I hingga periode II di mana pegawai, mahasiswa dan dosen mulai melakukan aktifitasnya di kampus, sedangkan lonjakan kendaraan keluar terjadi pada periode IV yang mana merupakan jam pulang kantor. Pada hari tersebut jumlah kendaraan roda dua yang tercatat memasuk area parkir sebanyak 2321 motor, sedangkan kendaraan roda empat yang tercatat memasuki area parkir sebanyak 261 mobil.

Volume parkir dihitung dengan menetapkan akumulasi kendaraan parkir tertinggi untuk roda-2 dan roda-4. Didapatkan jumlah kendaraan parkir roda2 tertinggi yaitu pada hari Selasa dengan jumlah kendaraan parkir sebanyak 833 motor, sedangkan jumlah kendaraan parkir roda-4 tertinggi yaitu pada hari Rabu dengan jumlah kendaraan parkir sebanyak 101 mobil.

Kebutuhan ruang parkir didapat dengan menghitung jumlah satuan ruang parkir (SRP) keseluruhan yang diperoleh dengan mengalikan volume kendaraan parkir tertinggi dengan satu SRP standar tiap jenis kendaraan.

Hitungan KRP kendaraan roda-2:

Jumlah KRP standar $=833 \times\left(0.70 \times 2.00 \mathrm{~m}^{2}\right)$

$$
=1166.2
$$

Hitungan KRP kendaraan roda-4:

Jumlah KRP standar $=101 \times\left(2.5 \times 5.00 \mathrm{~m}^{2}\right)$

$$
=1262.5
$$

Dari perhitungan Parking Turn Over (PTO) diketahui bahwa tingkat pergantian parkir mobil dan motor pada keempat periode pengamatan, satu petak parkir dipakai oleh 2 kendaraan saja dalam tiga jam.

Dari penghitungan kebutuhan ruang parkir didapatkan untuk kendaraan roda empat jumlah ruang parkir tersedia adalah 92 petak parkir, sedangkan ruang petak parkir roda dua tersedia adalah 825. Jika dibandingkan dengan akumulasi parkir maksimum di mana akumulasi maksimum mobil adalah 101 dan akumulasi maksimum motor adalah 833 pada harihari tidak terlalu ramai seperti pada saat pegambilan data, maka petak parkir yang tersedia tidak memenuhi. Untuk kendaraan roda empat paling tidak membutuhkan $1162 \mathrm{~m}^{2}$ ruang parkir, sedangkan kendaraan roda dua paling tidak membutuhkan $1262 \mathrm{~m}^{2}$ Pada harihari perkuliahan normal, jumlah akumulasi kendaraan dapat meningkat dua kali lipat, sehingga diperlukan ruang parkir yang lebih besar.

Dari data hasil perhitungan PTO dapat diketahui bahwa dalam tiap tiga jam, ruang parkir baik motor maupun mobil hanya mampu melayani dua kendaraan saja. Nilai PTO yang rendah ini mengindikasikan bahwa kendaraan 
yang parkir adalah kendaraan yang parkir secara long term. Dari penghitungan PTO dapat dilihat tingkat PTO tertinggi ada pada periode II yaitu pukul 09.01-12.00 adalah waktu-waktu tersibuk dimana mahasiswa dan dosen memulai menjalankan aktifitasnya di kampus. Selain itu, pada periode waktu ini juga kendaraan logistik untuk kantin juga beroperasi. Dengan waktu parkir kurang lebih tiga jam untuk satu kendaraan, jika dibandingkan dengan ruang parkir yang ada maka pada jam-jam tersibuk (periode II) kendaraan yang datang melimpah namun area parkir yang bisa ditempati kurang.

Pergerakan manusia di tiga fakultas Universitas Hasanuddin yaitu Fakultas Teknik, Fakultas MIPA dan Fakultas Farmasi yang beragam dikarenakan jadwal tiap fakultas yang berbeda-beda mengakibatkan adanya perbedaan kebutuhan akan ruang gerak kendaraan sebagai pengangkut manusia, salah satunya ruang parkir. Gedung ketiga fakultas ini sebelum tahun 2011 belum begitu terintegrasi, sehingga belum terjadi konsentrasi orang dan kendaraan yang padat. Saat ini, dengan adanya gedung baru Fakultas Farmasi dan Fakultas MIPA yang dibangun persis disebelah Fakultas Teknik tentu mempengaruhi fasilitas parkir yang telah ada sebelumnya. Kepadatan parkir yang terjadi dapat dilihat indikasinya pada volume kendaraan baik kendaraan roda empat maupun kendaraan roda dua yang melebihi jumlah petak parkir yang ada, walaupun dalam kondisi kampus yang tidak begitu ramai (sedang masa Ujian Akhir Semester). Dengan kondisi perparkiran tersebut, Fakultas Teknik, Fakultas Farmasi dan Fakultas MIPA membutuhkan penataan perparkiran yang lebih baik.

Solusi yang ditawarkan untuk mengatasi permasalahan penataan perparkiran tersebut adalah dengan mengubah layout parkir terutama area parkir mobil utama Fakultas Teknik (A.1) dan area parkir motor gedung TNR Fakultas Teknik (C.2) dengan menggabungkan kedua area parkir tersebut. Akses masuk mobil ke dalam area parkir di tambahkan melalui jalan masuk lama gedung PBT fakultas Teknik yang saat ini dialihfungsikan menjadi parkiran sepeda motor di sisi kiri (C.7) dan kanan (C.6) badan jalan. Area parkir sepeda motor ini kemudian dipindahkan ke dalam area parkir mobil sehingga hanya menyediakan satu area parkir badan jalan di sebelah kiri (C.7). 
Untuk parkiran sepeda motor, drainase yang baik, taman yang sejuk dan sebaiknya dilakukan sentralisasi parkiran dengan mendirikan bangunan parkir di area parkiran motor Fakultas MIPA (C.3). Gedung ini bisa berupa gedung dengan tiga atau empat lantai menggunakan konstruksi dan desain terbaru yang dapat menampung motor di Fakultas Teknik, Fakultas MIPA dan Fakultas Farmasi.

Dengan menggunakan layout tersebut, didapatkan tambahan petak parkir baru untuk kendaraan roda empat hingga mampu menampung 105 kendaraan dan 1 petak kendaraan untuk penyandang disabilitas, tata layout ini juga bisa dikembangkan apabila terjadi permintaan kendaraan tanpa menimbulkan lingkungan kumuh.

\section{KESIMPULAN DAN SARAN}

Hasil penelitian dan pembahasan dapat ditarik kesimpulan bahwa kapasitas ruang parkir yang tersedia di area parkir Fakultas Teknik, Fakultas MIPA dan Fakultas Farmasi ditinjau dari tata layout bangunan adalah tidak layak dan over capacity. Konsep penataan ruang parkir yang efektif adalah memperbaiki layout parkiran roda empat dan pembangunan gedung parkir motor yang digabungkan. Peneliti menyarankan peningkatkan kapasitas ruang parkir dengan melakukan perbaikan tata ruang parkir yang aman, akses pejalankaki yang nyaman serta mengalokasikan anggaran untuk pembangunan gedung parkir motor yang baik

\section{DAFTAR PUSTAKA}

Abubakar dkk. (1998). Pedoman Perencanaan dan Pengoperasian Fasilitas Parkir. Jakarta:

Direktorat Jenderal Perhubungan Darat.

Balsas C. J. (2003). Sustainable Transportation Planning on College Campuses. Transport Policy, 10(1), 35-49.

Barata E \& Ferreira J.P. (2011). Parking at the UC Campus: Problems and Solutions. Cities, 28(5), 406-413.

Goyal S \& Gomes L. (1984). A Model for Allocating Car Parking Spaces in Universities. Transportation Research Part-B, 18(3), 267-269.

Morlok E. K. (2010). Pengantar Teknik dan Perencanaan Transportasi. Jakarta: Erlangga.

Rotaris L \& Danielis R. (2014). The Impact of Transportation Demand Management Policies on Commuting to College Facilities: A Case Study at the University of Trieste, Italy. Transportation Research Part-A, 67, 127-140.

Riggs W. (2014). Dealing with Parking Issues on an Urban Campus: The Case of UC

Berkeley. Case Study on Transport Policy. Diakses 1 Januari 2015. Available from:

http://dx.doi.org/10.1016/j.cstp.2014.07.0 09.

Riggs W \& Kuo J. (2015). The Impact of Targeted Outreach for Parking Mitigation on the UC Berkeley Campus. Case Studies on Transport Policy, 3(2), 151-158. 
Shang H., Lin W. \& Haijun H. (2007). Empirical Study of Parking Problem on University

Campus. Journal of Transportation Systems Engineering and Information Technology, 7(2), 135140.

Soejono. (1996). Pedoman Teknis Penyelenggaraan Fasilitas Parkir. Jakarta: Keputusan Direktorat Jenderal Perhubungan Darat No. 272/HK.105/DRJD/96 